\title{
Assessment of Bacteriological Quality of Street Vended Fast Foods and their Antimicrobial Resistance
}

\author{
Abdullah Al Momen Sabuj, Zobayda Farzana Haque, Nanda Barua, \\ Md. Alimul Islam and Sukumar Saha"
}

Department of Microbiology and Hygiene, Bangladesh Agricultural University, Mymensingh-2202, Bangladesh

*Corresponding author

\begin{tabular}{|l|}
\hline K e y w or d s \\
$\begin{array}{l}\text { Street vended fast } \\
\text { food, Total bacterial } \\
\text { load, Antimicrobial } \\
\text { susceptibility test }\end{array}$ \\
\hline Article Info \\
\hline $\begin{array}{l}\text { Accepted: } \\
\text { 26 October } 2018 \\
\text { Available Online: } \\
\text { 10 November } 2018\end{array}$ \\
\hline
\end{tabular}

\section{A B S T R A C T}

The present study was conducted to determine the total bacterial load with special emphasis on Staphylococcus spp., Salmonella spp. and Escherichia coli in street vended fast foods sold in Bangladesh Agricultural University campus, Mymensingh and to evaluate the antibiotic resistance of isolates. A total of 72 samples from six street vended fast food items included Shingara, Samosa, Piazu, Puri, Potato chop and Beguni were collected. Bacterial enumeration and antimicrobial susceptibility test were made using the following standard microbiological methods. The mean total bacterial count, Staphylococcus spp., Salmonella spp. and E. coli count in all the fast food samples ranged from $1.0 \times 10^{7}$ to $2.4 \times 10^{7}, 6.3 \times 10^{3}$ to $4.2 \times 10^{4}, 2.4 \times 10^{3}$ to $3.2 \times 10^{4}$ and $2.7 \times 10^{4}$ to 4.0 x $10^{4} \mathrm{cfu} / \mathrm{g}$ respectively. Among the 60 isolates, Staphylococcus spp. was most detected isolate $(40 \%)$ followed by E. coli $(33.3 \%)$ and Salmonella spp. (26.7\%). All the isolates were tested to antibiotic susceptibility against ten commonly used antibiotics and the results showed most of the bacterial isolates were resistant to ampicillin, amoxicillin, nalidixic acid, tetracycline and erythromycin whereas many of the isolates of these organisms were sensitive to ciprofloxacin, gentamycin, azithromycin and chloramphenical. Thus the study revealed that street vended fast food in this area is contaminated with foodborne bacteria that can pose a serious health problem.

\section{Introduction}

Street fast food refers to the state of food and beverages that are prepared or sold by vendors in streets and other public places for direct human consumption immediately or later, with or without need for further processing and preparation (Tsang, 2002). In developing country like Bangladesh, it is getting popular day by day due to cheap price and easily available and convenient in urban habitant.
For this reason, without following the rule of food safety and hygiene, an increasing number of shops are getting established throughout the Bangladesh (Ahmed et al., 2008).

Fast foods are easy to prepare and serve. Samosa, shingara, vegetable roll, chicken roll, sandwich, pakura, puri, chop, cake, patties and burgar are most popular fast food in Bangladesh (Rahman et al., 2014). Fast foods are served as snacks in meeting, seminar, any 
festival and most of the students take those during the tiffin period as alternative regular food items. Most of the ingredients used in fast food are nutritious but they harbor various pathogenic organism including Escherichia coli, Enterobacter spp. Staphylococcus aureus, Salmonella spp. and Listeria monocytogens (Ahmed et al., 2014).

Street fast foods contribute a significant role in foodborne illness to consumers. Most of the food handlers and worker are uneducated and lack of the knowledge about handling practice, sanitation and hygiene so that food can easily be contaminated (Tabashsum et al., 2013). There are several reason for contamination of street fast foods includes the utensils and equipment that enhance cross contamination, vending sites that are filthy in nature, tap water used in preparation of food, waste and garbage produce in restaurants discard nearby that attract the rodents and insect which may carry foodborne pathogens, flies that land on food sporadically and finally handling of food by vendors with bare hand (Nicolas et al., 2007; Tambekar et al., 2009).

Foodborne illness is occurred after consumption of contaminated foods containing microorganisms and their toxin (Clarence et al., 2009). It is now becoming a great concern involving a wide range of illness caused by bacterial, viral, parasitic and chemical contamination of food. In addition, resistant to multi-drug against these organisms is a great concern of public health (Tabashsum et al., 2013). It is stated that approximately 30 million people in Bangladesh getting infected from foodborne illness each year (FAO, 2012). The incidence of foodborne illness is on the rise worldwide and becomes an alarming issue involving broad range of disease caused by the pathogenic organisms (De Vogli et al., 2014). Most of the bacteria present in foods are resistant to antibiotic and it is very difficult to control them and sometimes it reaches at such as level that can cause death of an individual stated by Ahmed et al., (2008).

Studies have been carried out in different countries throughout the world to investigate the microbiological quality of street fast food. Eromo et al., (2016) isolated three bacteria from six street food items in Hawassa, Ethiopia where $29.6 \%$ of $E$. coli followed by $12.7 \%$ of Salmonella spp. and $9.9 \%$ of $S$. aureus. Adimasu et al., (2016) identified $E$. coli, S. aureus and Salmonella spp. in street vended foods in Gondar, Ethiopia. Manguiat and Fang (2013) were found higher number of coliforms, E. coli and S.aureus in pork and chicken based food samples. Kibret and Tadesse (2013) also identified contamination in lupin by Salmonella spp., Shigella spp. and E. coli. Sharma and Mazumdar (2014) carried out the experiment on street food samples in Silchar city, India and the isolates recovered was $37.5 \%$ E. coli, $5.35 \%$ Salmonella, $19.94 \%$ Shigella and remaining percentage was other microbial species. In Orissa, India $E$ coli, Klebsiella spp. Vibrio spp. Shigelladysenteriae and Salmonella paratyphi were detected in Panipuri samples by Das et al., (2012).

Popularity of street fast foods is increasing day by day among the all ages. About 10 thousand students are studying in Bangladesh Agricultural University. The university is considered as one of the densely populated areas in Mymensingh and is surrounded by a number of food vendors and restaurants. So, there is lots of chance of getting infection through consumption of fast food from these street vended restaurants. Considering above mentioned facts, this study was carried out to assess the total bacterial load and also isolation, identification and antimicrobial susceptibility of common bacterial pathogen with special emphasis on Staphylococcus spp., Salmonella spp. and Escherichia coli in street vended fast foods. 


\section{Materials and Methods}

\section{Sample collection}

The study was carried out on street vended fast foods sold in Bangladesh Agricultural University, Mymensingh, Bangladesh during the period of January 2017 to December 2017. For this purpose, a total of 72 fast food samples comprising six items (Shingara, Samosa, Piazu, Puri, Potato chop and Beguni) were randomly collected from different street vended restaurants including Jabbarer More (5 restaurants), Kamal-Ranjit Market (3 restaurants), Kewatkhali (2 restaurants) and Shesh More ( 2 restaurants). These fast foods items and places were selected as per as consumer preference and their availability. After collection, samples were kept in labeled sterile polyethylene containers and transported to the Bacteriology laboratory, Department of Microbiology and Hygiene, Bangladesh Agricultural University in cold box (contain ice blocks) and processed immediately for bacteriological analysis.

\section{Sample processing}

For analysis, $10 \mathrm{~g}$ of samples were weighed using electric balance and blended in mortar and pestle. After that samples were homogenized properly with $90 \mathrm{ml}$ of phosphate buffered saline (PBS) solution. Serial dilutions of $10^{-1}$ to $10^{-6}$ were made depending upon contamination level using $1 \mathrm{ml}$ of homogenized sample with $9 \mathrm{ml}$ of PBS.

\section{Microbial analysis}

All the media were prepared according to Manufacture's instruction, and sterilized by autoclaving for 15 mins at $121^{\circ} \mathrm{C}$. Salmonellashigella agar (SS) which did not require autoclaving, were sterilized by boiling for 15 mins according to the instruction of manufacturer's. Nutrient agar was used to count the total bacterial colonies. A $0.1 \mathrm{ml}$ aliquot from each dilution was inoculated onto the center of petridishes of nutrient agar and spread by a glass stick smoothly. Then it was kept in incubator at $37^{\circ} \mathrm{C}$ for 24 to $48 \mathrm{hrs}$ in an inverted position. After incubation, colonies on nutrient agar were counted and recorded in cfu/g of fast food samples. Similar method was applied to enumerate the Staphylococcus spp., Salmonella spp. and E. coli using Mannitol-salt agar, Salmonella-shigella agar and Eosin methylene blue agar respectively.

\section{Isolation and identification of bacteria}

For obtaining pure culture, bacterial colonies of different agar were streaked in their respective media and incubated overnight at $37^{\circ} \mathrm{C}$. Bacteria was identified on the basis of colony characteristics, morphological characteristics by Gram's staining, sugar fermentation test and a series of biochemical tests including Methyl red (MR), VogesProskauer (VP), Catalase and coagulase test (Cheesbrough, 2006).

\section{Molecular detection by PCR}

Genus specific PCR was performed to identify the microorganisms using previously published primers. The lists of primers and their oligonucleotide sequences are shown in Table 1. Genomic DNA was extracted from each isolate by heat lysis method as described

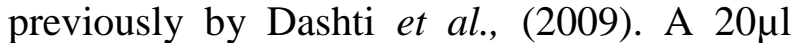
reaction mixture was used comprising $4 \mu \mathrm{l}$ PCR master mix (MP Bio Medical), $1 \mu 1$ forward primer, $1 \mu 1$ reverse primer, $9 \mu 1$ nuclease free water and $5 \mu 1$ DNA template. Thermal condition used for amplification was 5 mins at $94^{\circ} \mathrm{C}$ for initial denaturation followed by 35 cycles comprising of denaturation at $94^{\circ} \mathrm{C}$ for $1 \mathrm{~min}$, annealing at $52^{\circ} \mathrm{C}$ for $1 \mathrm{~min}$, extension at $72^{\circ} \mathrm{C}$ for $1 \mathrm{~min}$ and final extension at $72^{\circ} \mathrm{C}$ for 10 mins in case of Staphylococcus spp. For Salmonella spp. 
amplification condition was 5 mins at $94^{\circ} \mathrm{C}$ for initial denaturation followed by 30 cycles of reaction comprising denaturation at $94^{\circ} \mathrm{C}$ for $30 \mathrm{~s}$, annealing at $66^{\circ} \mathrm{C}$ for $30 \mathrm{~s}$, extension at $72^{\circ} \mathrm{C}$ for $45 \mathrm{~s}$ and final extension at $72^{\circ} \mathrm{C}$ for 10 mins.

Thermal condition used for amplification of $E$. coli was 5 mins at $95^{\circ} \mathrm{C}$ for initial denaturation followed by same reaction cycle used in Salmonella spp. consisting at denaturation at $94^{\circ} \mathrm{C}$ for $40 \mathrm{~s}$, annealing at $56^{\circ} \mathrm{C}$ for $30 \mathrm{~s}$, extension at $72^{\circ} \mathrm{C}$ for $30 \mathrm{~s}$ and final extension at $72^{\circ} \mathrm{C}$ for 7 mins. After that $5 \mu \mathrm{l}$ of PCR products was loaded in $1.5 \%$ agarose gel well and electrophoresed in $1 \mathrm{X}$ TAE buffer for 25 mins at $100 \mathrm{~V}$. Ethidium bromide was used to stain the DNA and then visualized under ultraviolet trans-illuminator (Biometra, Germany).

\section{Antimicrobial susceptibility test}

Kirby-Bauer disc diffusion method described by Bauer et al., (1966) was used to perform antimicrobial susceptibility test on Mueller Hinton agar using the following antibiotic discs includes ampicillin $(25 \mu \mathrm{g})$, gentamycin $(10 \mu \mathrm{g})$, ciprofloxacin $(5 \mu \mathrm{g})$, azithromycin $(30 \mu \mathrm{g})$, chloramphenicol $(30 \mu \mathrm{g})$, tetracycline $(30 \mu \mathrm{g})$, neomycin $(30 \mu \mathrm{g})$, erythromycin $(5 \mu \mathrm{g})$, nalidixic acid $(30 \mu \mathrm{g})$ and amoxicillin $(30 \mu \mathrm{g})$. Antimicrobial agents tested in this study were selected on the criteria of commercially availability and widely used as treatment of bacterial diseases. The zone sizes of bacteria were compared with standard of Clinical and Laboratory Standards Institute (CLSI, 2016).

\section{Statistical analysis}

All data was incorporated in SPSS software (SPSS-20.0) and analyzed. Descriptive analysis was performed to calculate mean and frequency.

\section{Results and Discussion}

During the investigation, a total of 72 street fast food samples were investigated to determine the microbial load. From this study, it was revealed that food samples examined from the various street vended restaurants were contaminated with indicator organisms including Staphylococcus spp., Salmonella spp. and E. coli. Bacteria enumerated from different types of food samples are shown in Table 2.

\section{Total bacterial count (TBC)}

In present study, all the six food items were examined for determination of total bacterial load and all of them were found to be contaminated. Total bacterial count in all the food items was recorded ranged from $1.0 \mathrm{x}$ $10^{7}$ to $2.4 \times 10^{7} \mathrm{cfu} / \mathrm{g}$ whereas highest one was estimated from piazu samples and lowest one from puri samples. TBC of samples from all the tested street vended restaurants were not within acceptable limit recognized by the International Commission for Microbiological Specification for Foods $\left(10^{6}\right.$ to $\left.<10^{7} \mathrm{cfu} / \mathrm{g}\right)$ (ICMSF, 2002). The count of TBC was relatively higher than the findings of Nguendo (2018) who found TBC ranged from $1.71 \mathrm{x}$ $10^{5} \mathrm{cfu} / \mathrm{g}$ to $3.71 \times 10^{5} \mathrm{cfu} / \mathrm{g}$ for different street foods and beverages in three location of Yaounde, Cameroon. Khandoker et al., (2014) was also reported TVC ranging from $10^{4}$ to $10^{5} \mathrm{cfu} / \mathrm{g}$ for spicy puffed rice sold by street vendors at Bangladesh Agricultural University campus, Bangladesh. Sharma and Mazumder (2014) examined the TBC in street fast food samples ranged from $4.5 \times 10^{5}$ to $1.12 \times$ $10^{6} \mathrm{cfu} / \mathrm{g}$ in Silchar city, Assam, India. On the other hand, mean TBC obtained in present study was quite comparable wiith the findings of Madueke et al., (2014) who observed average mean bacterial count ranging from 5.0 x $10^{4}$ to $2.08 \times 10^{7} \mathrm{cfu} / \mathrm{g}$ forakara and fish, respectively in Lokoja-Abuja Express Way, 
Lokoja. The variations of TBC with the other research might be due to types of sampled food items, number of food samples, food content, way of preparation, handling and serving of foods by vendors. Environment and personal hygiene along with prolong exposure of foods to the different environmental conditions might be other cause of differences.

\section{Total Staphylococcal count}

Among the all tested food samples, 95\% (68/72) of them was found to be contaminated with Staphylococcus spp. The Staphylococcal countin food items ranged from $6.3 \times 10^{4}$ to 4.2 $\mathrm{x} 10^{5} \mathrm{cfu} / \mathrm{g}$. Among the all samples highest Staphylococcus spp. was found in puri and lowest in piazu samples. This finding was some extent comparable with the findings of Adimasu et al., (2016) who obtained $1.5 \times 10^{4}$ $\mathrm{cfu} / \mathrm{g}$ of $S$. aureus from street vended foods in Goinder, Ethiopia. Similarly, Wimalasekara and Gunasena (2016) also found $10^{4} \mathrm{cfu} / \mathrm{g}$ in meat based fast food samples in Colombo, Srilanka which was quite similar to present research. But present findings disagreed with the research of Khater-Dalia et al., (2013) and Cho et al., (2011) that documented $10^{2} \mathrm{cfu} / \mathrm{g}$ and $10^{3} \mathrm{cfu} / \mathrm{g}$ of Staphylococcus spp. in fast food samples of Tanta city, Egypt and Korea respectively which was comparatively lower than the present findings. Hoque et al., (2012) noted $10^{5} \mathrm{cfu} / \mathrm{g}$ of Staphylococcal count in sandwich collected from fast food outlets of Dhaka and Mymensingh city, Bangladesh that was slightly higher than the current study. Among the Staphylococcus spp. contaminated food samples, $78 \%(53 / 68)$ samples exceed acceptable range $\left(10^{4} \mathrm{cfu} / \mathrm{g}\right)$ of Staphylococcus spp. which indicates that tested fast food samples are hazardous to health. This variation might happen because it is stated that the presence of Staphylococcus was an indication of contamination from the skin and mouth or nose of food handlers. Tambekar et al., (2009) stated that lack of adequate knowledge on hygiene practices and food safety and contaminated hands of vendors may enhance the contamination.

\section{Total Salmonella spp. count}

In this study, 27\% (20/72) samples were found to be contaminated with Salmonella spp. and all of them crossed the acceptable limit as according to ICMSF (2002) no Salmonella will be detected in $25 \mathrm{~g}$ of samples. Total Salmonella count ranged from $2.4 \times 10^{3}$ to 3.2 x $10^{4} \mathrm{cfu} / \mathrm{g}$. The count of Salmonella was the highest in potato chop and lowest in samosa samples whereas no Salmonella was detected in piazu samples. The present finding agrees with several previous reports such as Akusu et al., (2016) in Rivers State, Nigeria who obtained $10^{3} \mathrm{cfu} / \mathrm{g}$ of Salmonella in egg burger, fried rice, meat pie and vegetable salad samples and Adimasu et al., (2016) was also found $1.6 \times 10^{3} \mathrm{cfu} / \mathrm{g}$ in street vended fast food samples in Gonder, Ethiopia. However, No Salmonella was detected in street food samples in different locations of Chennai city reported by Arunaand Rajan (2017). The presence of Salmonella spp. in this study may due to in clothing, handling and serving practices of vendors.

\section{Total E. coli count}

From results, E. coli count was estimated from $2.7 \times 10^{4}$ to $4.0 \times 10^{4} \mathrm{cfu} / \mathrm{g}$ which crossed the acceptable range where the range is $2 \mathrm{log}$ CFU/g (ICMSF, 2002). This indicates the high amount of $E$. coli were present on investigated fast food samples which can induce infection. Similar results were also observed by other researchers include Nguendo (2018) who reported $4.10 \times 10^{3} \mathrm{cfu} / \mathrm{g}$ of bacteria in fast samples in three location of Yaounde, Cameroon and Tabashsum et al., (2013) who seen $10^{2}$ to $10^{7} \mathrm{cfu} / \mathrm{g}$ of $E$. coli in different street foods of Dhaka city. Similarly, Amissah and Owusu (2012) carried out a study in 
Koforidua Polytechnic campus, Ghana and the results showed $1.0 \times 10^{3} \mathrm{cfu} / \mathrm{g}$ of $E$. coli in fast foods which was comparable to our study. Such variation in study could be linked with the use of unhygienic water for cleaning utensils and cooking of foods, secondary contamination via contact with contaminated equipment's.

Table.1 Oligonucleotide sequence of primers for PCR

\begin{tabular}{|c|c|c|c|}
\hline Primer & Sequence & $\begin{array}{l}\text { Size } \\
\text { (bp) }\end{array}$ & References \\
\hline $\begin{array}{l}\text { Staphylococcus } \\
\text { spp.16S (F) }\end{array}$ & 5'-GGAGGAAGGTGGGG ATGACG-3' & \multirow[t]{2}{*}{241} & \multirow[t]{2}{*}{$\begin{array}{l}\text { Stuhlmeier and } \\
\text { Stuhlmeier, } 2003\end{array}$} \\
\hline $\begin{array}{l}\text { Staphylococcus spp. } \\
\text { 16S (R) }\end{array}$ & 5'-ATGGTGTGACGGGC GGTGTG-3' & & \\
\hline $\begin{array}{l}\text { Salmonella common } \\
\text { (F) }\end{array}$ & $\begin{array}{l}5^{\prime}- \\
\text { ACTGGCGTTATCCCTTTCTCTGGTG-3' }\end{array}$ & \multirow[t]{2}{*}{496} & \multirow[t]{2}{*}{ Cohen et al., 1993} \\
\hline $\begin{array}{l}\text { Salmonella common } \\
\text { (R) }\end{array}$ & $\begin{array}{l}5^{\prime} \text { - } \\
\text { ATGTTGTCCTGCCCCTGGTAAGAGA- } \\
3^{\prime}\end{array}$ & & \\
\hline Escherichia coli (F) & 5'-AATTGAAGAGTTTGATCATG-3' & \multirow{2}{*}{704} & \multirow[t]{2}{*}{ Guan et al., 2002} \\
\hline Escherichia coli (R) & 5'-CTCTACGCATTTCACCGCTAC-3' & & \\
\hline
\end{tabular}

Note: $\mathrm{F}=$ Forward, $\mathrm{R}=\mathrm{Reverse}$ and $\mathrm{bp}=$ Base pair

Table.2 Mean total bacteria, Staphylococcus spp., Salmonella spp. and E. coli counts in street vended fast foods

\begin{tabular}{|l|l|l|l|l|l|}
\hline $\begin{array}{l}\text { Food } \\
\text { items }\end{array}$ & $\begin{array}{l}\text { Number } \\
\text { of } \\
\text { samples }\end{array}$ & \multicolumn{4}{|c|}{ Mean bacterial colony count (cfu/g) } \\
\cline { 3 - 7 } & $\begin{array}{l}\text { Total } \\
\text { bacterial } \\
\text { count } \\
\text { (cfu/g) }\end{array}$ & $\begin{array}{l}\text { Staphylococcus } \\
\text { spp. count } \\
\text { (cfu/g) }\end{array}$ & $\begin{array}{l}\text { Salmonella } \\
\text { spp. count } \\
\text { (cfu/g) }\end{array}$ & $\begin{array}{l}\text { E. coli } \\
\text { (cfu/g) }\end{array}$ \\
\hline Shingara & 12 & $1.6 \times 10^{7}$ & $1.0 \times 10^{5}$ & $5.0 \times 10^{3}$ & $3.2 \times 10^{4}$ \\
\hline Samosa & 12 & $1.7 \times 10^{7}$ & $1.5 \times 10^{5}$ & $2.4 \times 10^{3}$ & $4.0 \times 10^{4}$ \\
\hline Piazu & 12 & $2.4 \times 10^{7}$ & $6.3 \times 10^{4}$ & - & $2.7 \times 10^{4}$ \\
\hline Puri & 12 & $1.0 \times 10^{7}$ & $4.2 \times 10^{5}$ & $2.0 \times 10^{4}$ & $3.7 \times 10^{4}$ \\
\hline $\begin{array}{l}\text { Potato } \\
\text { chop }\end{array}$ & 12 & $2.0 \times 10^{7}$ & $1.1 \times 10^{5}$ & $3.2 \times 10^{4}$ & $3.8 \times 10^{4}$ \\
\hline Beguni & 12 & $1.7 \times 10^{7}$ & $8.4 \times 10^{4}$ & $2.1 \times 10^{4}$ & $2.9 \times 10^{4}$ \\
\hline
\end{tabular}

* According to the International Commission for Microbiological Specification for Foods (ICMSF, 2002), Acceptable range of TBC, Staphylococcus and E. coli are $10^{6} \mathrm{cfu} / \mathrm{g}(6 \log \mathrm{cfu} / \mathrm{g}) ; 10^{4} \mathrm{cfu} / \mathrm{g}(4 \log \mathrm{cfu} / \mathrm{g}) ;$ and $10^{2} \mathrm{cfu} / \mathrm{g}$ ( $2 \log \mathrm{cfu} / \mathrm{g}$ ) respectively and detection of Salmonella spp. in $25 \mathrm{~g}$ sample is unacceptable. 
Table.3 Bacterial isolates of street vended fast foods

\begin{tabular}{|c|c|c|c|c|c|c|c|}
\hline \multirow[t]{2}{*}{ Identified organism } & \multicolumn{6}{|c|}{ Food items } & \multirow{2}{*}{$\begin{array}{c}\text { Total } \\
\text { bacterial } \\
\text { isolates }(\%)\end{array}$} \\
\hline & Shingara & Samosa & Piazu & Puri & $\begin{array}{l}\text { Potato } \\
\text { chop }\end{array}$ & Beguni & \\
\hline Staphylococcus spp. & $5(20.8)$ & $4(16.7)$ & $2(8.3)$ & $6(25)$ & $4(16.6)$ & $3(12.5)$ & $24(40)$ \\
\hline Salmonella spp. & $3(18.7)$ & $1(6.2)$ & $0(0)$ & $4(25)$ & $4(25)$ & $4(25)$ & $16(26.7)$ \\
\hline E. coli & $4(20)$ & $4(20)$ & $3(15)$ & $3(15)$ & $4(20)$ & $2(10)$ & $20(33.3)$ \\
\hline Total & $12(20)$ & $9(15)$ & $5(8.3)$ & $13(21.7)$ & $12(20)$ & $9(15)$ & $60(100 \%)$ \\
\hline
\end{tabular}

* Percentages were calculated by dividing the number of isolates in a particular food items by total number of isolates

Table.4 Antimicrobial resistance pattern of bacterial isolates from ready to eat fast food samples

\begin{tabular}{|c|c|c|c|c|c|c|c|c|c|c|}
\hline & \multicolumn{10}{c|}{ Antibiotics tested } \\
& AMP & GEN of resistance & CIP & AZM & C & TE & N & E & NA & AMX \\
\hline Staphylococcus & 24 & 6 & 0 & 4 & 8 & 20 & 14 & 20 & 24 & 24 \\
spp. (n=24) & $(100)$ & $(25)$ & $(0)$ & $(16.7)$ & $(33.3)$ & $(83.3)$ & $(58.3)$ & $(83.3)$ & $(100)$ & $(100)$ \\
\hline Salmonella spp. & 16 & 4 & 0 & 2 & 4 & 14 & 8 & 12 & 16 & 16 \\
$(\mathbf{n}=\mathbf{1 6})$ & $(100)$ & $(25)$ & $(0)$ & $(12.5)$ & $(25)$ & $(87.5)$ & $(50)$ & $(75)$ & $(100)$ & $(100)$ \\
\hline E. coli & 20 & 6 & 0 & 4 & 6 & 16 & 6 & 16 & 18 & 20 \\
$(\mathbf{n}=\mathbf{2 0})$ & $(100)$ & $(30)$ & $(0)$ & $(20)$ & $(30)$ & $(80)$ & $(30)$ & $(80)$ & $(90)$ & $(100)$ \\
\hline
\end{tabular}

Legends: AMP=Ampicillin; GEN=Gentamycin; CIP=Ciprofloxacin; AZM=Azithromycin; $\mathrm{C}=\mathrm{Chloramphenicol;}$ $\mathrm{TE}=$ Tetracycline; $\mathrm{N}=$ Neomycin; $\mathrm{E}=$ Erythromycin; NA=Nalidixic acid and $\mathrm{AMX}=$ Amoxicillin

\section{Identification of bacteria}

In this study microbiological methods were used to identify bacteria from the street fast foods. The results of cultural characteristics, Gram's staining, biochemical tests and genus specific PCR used to identify the microorganisms were similar to the findings of previously published paper. Konuku et al., (2012) stated that Staphylococcus spp. on mannitol salt agar showed colonies that fermented mannitol and appeared golden yellow. Salmonella spp. produced small round black center colonies on Salmonella-Shigella (SS) agar which was in agreement with the study of Muktaruzzaman et al., (2010). E. coli on Eosin Methylene Blue (EMB) agar plate appeared as dark with characteristics metallic sheen as indicated by El-Aziz et al., (2014).
Among the identified bacteria Staphylococcus spp. and E. coli were most frequently isolated whereas Salmonella spp. was prevalent in only five food items except piazu. A total of 60 isolates of three organisms were identified. Among the isolates, $40 \%$ (24) were Staphylococcus spp. followed by $33.3 \%$ (20) E. coli and $26.7 \%$ (16) Salmonella spp. (Table $3)$. The highest number of bacteria was isolated from Puri (13/60) and lowest number in piazu sample $(5 / 60)$. This variation might be associated with the ingredient that was used for preparation of particular food. The percentages of different types of bacteria recovered from the food samples were incomparable with the findings of Bereda et al., (2016) who reported $84.6 \%$ of S. aureus, $51.5 \%$ of E. coli and $19.7 \%$ of Salmonella spp. in street vended foods of Jigjaj city of 
Ethiopia that was comparatively higher than our study. The same types of bacteria were isolated in several previous studies includes in street vended foods of Rivers state Nigeria by Akusu et al., (2016), in selected street foods of Gondar town, Ethiopia by Adimasu et al., (2016) and in street food of Silchar city, Assam, India by Sharma and Mazumdar (2014).

\section{Antimicrobial susceptibility test}

From the antimicrobial susceptibility test results, it was revealed that $70-100 \%$ isolates of three organisms showed resistant to ampicillin, amoxicillin, nalidixic acid, tetracycline and erythromycin which would make the treatment of infections difficult (Table 4). However, ciprofloxacin was $100 \%$ sensitive to all isolates. The isolates of Staphylococcus showed sensitive against gentamycin (75\%), azithromycin $(83.33 \%)$ and chloramphenicol $(66.67 \%)$ respectively. About $75 \%$ of isolates Salmonella spp. showed sensitive to gentamycin followed by $87.5 \%$ to azithromycin and $75 \%$ chloramphenicol respectively and similar results were also observed in E. coli.

That means this drug still can be used as a choice of treatment of foodborne illness in this area. This study completely agreed with the previous study conducted by Sultana et al., (2015) who observed highest resistance rate for ampicillin, cephalexin and vencomycin against $S$. aureus. This result was also some extent comparable with the findings of Eromo et al., (2016) who reported that $89 \%$ isolates of Salmonella spp. and $14.3 \%$ of $S$. aureus were resistant to chloramphenicol and vancomycin respectively whereas ciprofloxacin was sensitive against all isolates in street foods of Hawassa, Ethiopia. Similar reports were also described by following researchers Khandokar et al., (2014), Sharma and
Mazumdar (2014) and Kalantari et al., (2012). Multi drug resistant bacteria pose a big challenge to human survival and continued existence in relation to bacterial infection and diseases. The results from this study show that street vended fast food samples are contaminated with various bacteria most of which are resistant to commonly used antibiotics and therefore represent risks and public health hazards.

The results of the current study clearly demonstrated that street vended fast foods sold in Bangladesh Agricultural University campus premises are contaminated with Staphylococcus spp., Salmonella spp. and E. coli. The existence of these bacteria in fast foods could cause potential public health problems for consumers. Poor personal hygiene, improper handling practices, prolong storage of foods in ambient temperature and lack of knowledge of restaurants operators towards food safety and foodborne infections were the associated factors to contamination of fast foods. Furthermore, the study revealed that majority of restaurants vendors did not have any food safety training. Moreover, multiple drug resistant bacteria from fast foods might act as a vector in the spread of antibiotic resistant strains in the community and environment. So, necessary information, education facilities and food safety training program should be ensured for all the restaurants vendors that can help to reduce the chance of infection and at the meantime provide safe and good quality foods to consumers.

Therefore, consumers should be aware of harmful effect of consumption street foods. Finally, regular inspection of fast foods vending site should be ensured by public health authority of respected country to improve the quality of street vended fast foods as well as to avoid foodborne disease outbreaks in community. 


\section{Acknowledgement}

The author would like to acknowledge the Ministry of Science and Technology, Bangladesh for the financial support and also grateful to Department of Microbiology and Hygiene, Bangladesh Agricultural University for the lab facilities to carry out the research work smoothly.

\section{References}

Adimasu, A., Mekonmen, B., Guadu T., Gizaw Z., Adane T. 2016. Bacteriological quality assessment of selected street foods and their public health importance in Gondar Town, North West Ethiopia. Glob Vet., 17:255264.

Ahmed, J., Hossain, M. L., Malek, M. A., Begum, F. 2008. Assessment of bacteriological quality of fast foods and soft drinks in relation to safety and hygiene. Bangla. J. Microbiol., 25:7375 .

Ahmed, S., Tasnim, U. T., Pervin, S., Islam, M. T. 2014. An assessment of bacteriological quality of some fast food items available in Jessore City and antibiotic susceptibility of isolated Klebsiella spp. Int J Biosci., 5: 125-130.

Akusu, O. M., Kiin-Kabari, D. B., Wemedo, S. A. 2016. Microbiological quality of selected street vended foods in Port Harcourt metropolis, Rivers State, Nigeria. Sky J. Food Sci., 5: 8-11.

Amissah, A., Owusu, J. 2012. Assessing the microbiological quality of food sold around Koforidua Polytechnic Campus of Ghana. Annal. Food Sci. Technol., 13: 60-67.

Aruna, N., Rajan, V. 2017. Microbial analysis of street foods of different locations at Chennai city, India. Innovat Int. J. Med. Pharma. Sci., 2: 21-23.
Bauer, A. W., Kirby, W. M. M., Sherris, J. C., Turck, M. $1966 . \quad$ Antibiotic susceptibility testing by a standardized single disk method. Am. J. ClinPathol., 45: 493-496.

Bereda, T. W., Emerie, Y. M., Reta, M. A., Asfaw, H. S. 2016. Microbiological safety of street vended foods in Jigjiga City, Eastern Ethiopia. Ethiop. J. Health Sci., 26: 163-172.

Cheesbrough, M. 2006. District laboratory practice in tropical countries. Cambridge university press.

Cho, J. I., Cheung, C. Y., Lee, S. M., Ko, S. I., Kim, K. H., Hwang, I. S., Kim, S. H., Cho, S. Y., Lim, C. J., Lee, K.H., Ha, S. D., Kim, K. S. 2011. Assessment of microbial contamination levels of street- vended foods in Korea. J. Food Safety, 31: 41-47.

Clarence, S. Y., Obinna, C. N., Shalom, N. C. 2009. Assessment of bacteriological quality of ready to eat food (Meat pie) in Benin City metropolis, Nigeria. Afr.J. Microbiol Res., 3: 390-395.

CLSI, 2016. Performance standards for antimicrobial susceptibility testing, $27^{\text {th }}$ informational supplement. Wayne, USA.

Cohen, N. D., Neibergs, H. L., McGruder, E. D., Whitford, H. W., Behle, R. W., Ray, P. M., Hargis, B. M. 1993. Genusspecific detection of salmonellae using the polymerase chain reaction (PCR). $J$. Vet. Diag. Invest. 5: 368-371.

Das, M., Rath, C. C., Mohapatra, U. B. 2012. Bacteriology of a most popular street food (Panipuri) and inhibitory effect of essential oils on bacterial growth. $J$. Food Sci. Technol., 49: 564-571.

Dashti, A. A., Jadaon, M. M., Abdulsamad, A. M., Dashti, H. M. 2009. Heat treatment of bacteria: A simple method of DNA extraction for molecular techniques. Kuwait Med. J., 41: 117122. 
De Vogli, R., Kouvonen, A., Gimeno, D. 2014. The influence of market deregulation on fast food consumption and body mass index: a cross-national time series analysis. Bull. World Health Organ, 92: 99-107.

El-Aziz, N. K. A., Eldesoky, I. E., Ammar, A. M., Eissa, S. I., Mohamed, Y. H. 2014. Molecular studies on M. gallisepticum and avian pathogenic E. coli induced infections in broilers. Eur. J. Vet. Med., 2014: 1-11.

Eromo, T., Tassew, H., Daka, D., Kibru, G. 2016. Bacteriological quality of street foods and antimicrobial resistance of isolates in Hawassa, Ethiopia. Ethiop. J. Health Sci., 26: 533-542.

FAO, 2012. The State of Food Insecurity in the World 2012. Economic growth is necessary but not sufficient to accelerate reduction of hunger and malnutrition. Rome, FAO. Available at: http://www.fao.org/3/a-i3027e.pdf.

Guan, S., Xu, R., Chen, S., Odumeru, J., Gyles, C. 2002. Development of a procedure for discriminating among Escherichia coli isolates from animal and human sources. App. Environ. Microbiol., 68: 2690-2698.

Hoque, N., Kabir, S. M. L., Rahman, M. M., Khan, M. S. R. 2012. Microbial quality of selected sandwiches sold at retail outlets of fast food shops in Dhaka city and Mymensingh town of Bangladesh. Sci. J. Microbiol., 1: 101-112.

ICMSF, 2002: Microorganisms in Foods 7: Microbiological testing in food safety Management. Kluwer Academic/Plenum Publishers.

Kalantari, S., Sepehri, G., Bahrampour, A., Sepehri, E. 2012. Determination of bacterial contamination isolated from Sandwiches in Kerman City and their resistance to commonly used antimicrobials. Arch. App. Sci. Res., 4: 1100-1105.
Khandoker, A., Islam, M. A., Rahman, M. M., Husna, A. A., Das, S., Khatun, M. M. 2015. Bacterial contamination of street-vended spicy puffed-rice sold at Bangladesh Agricultural University campus. Bangla. Vet., 31: 20-26.

Khater-Dalia, F., Heikal, G. E., Shehata, A. A, El-Hofy, F. I. 2013. The microbiological assessment of ReadyTo-Eat-Food (Liver and Kofta Sandwiches) in Tanta City, Egypt. Benha Vet. Med. J., 25: 187-197.

Kibret, M., Tadesse, M. 2013. The bacteriological safety and antimicrobial susceptibility of bacteria isolated from street-vended white lupin (Lupinus albus) in Bahir Dar, Ethiopia. Ethiop. J. Health Sci. 23: 19-26.

Konuku, S., Rajan, M. M., Muruhan, S. 2012. Morphological and biochemical characteristics and antibiotic resistance pattern of Staphylococcus aureus isolated from grapes. Int. J. Nutr. Pharmacol. Neurol. Dis., 2: 70-73.

Madueke, S. N., Awe, S., Jonah, A. I. 2014. Microbiological analysis of street foods along Lokoja-Abuja express way, Lokoja. Am. J. Res. Commun., 2: 196211.

Manguiat, L. S., Fang, T. J. 2013. Microbiological quality of chicken-and pork-based street-vended foods from Taichung, Taiwan, and Laguna, Philippines. Food Microbiol, 36: 57-62.

Muktaruzzaman, M., Haider, M. G., Ahmed, A. K. M., Alam, K. J., Rahman, M. M., Khatun, M. B., Rahman, M. H., Hossain, M. M. 2010. Validation and refinement of Salmonella pullorum (SP) colored antigen for diagnosis of Salmonella infections in the field. Int. $J$. Poult. Sci., 9: 801-808.

Nguendo, Y. H. B. 2018. Eating to live or eating to damage one's health: Microbiological risks associated with street-vended foods in a subtropical 
urban setting (Yaoundé-Cameroon). Nutr.Food Sci. Int. J., 6: 555695.

Nicolas, B., Razack, B. A., Yollande, I., Aly, S., Tidiane, O. C. A., Philippe, N. A., Comlan, D.S., Sababénédjo, T. A. 2007. Street-vended foods improvement: Contamination mechanisms and application of Food Safety Objective Strategy: Critical review. Pak. J. Nutr., 6: 1-10.

Rahman, M. M., Rahman, M. H., Ansary, N. P. 2014. Safety issues of street foods in Bangladesh. Time J. Biol. Sci. Technol., 2: 21-32.

Sharma, I., Mazumdar, J. A. 2014. Assessment of bacteriological quality of ready to eat food vended in streets of Silchar city, Assam, India. Indian J. Med.Microbiol., 32: 169-171.

Stuhlmeier, R., Stuhlmeier, K. M. 2003. Fast, simultaneous, and sensitive detection of staphylococci. J. Clin. Pathol., 56: 782785.

Sultana, S., Islam, M. A., Khatun, M. M. 2015.Bacteria in chicken rolls sold by fast food restaurant and their public health significance. Bangla. Vet. 32: 1318.

Tabashsum, Z., Khalil, I., Nazimuddin, M. D., Mollah, A. K. M., Inatsu, Y., Bari, M. L. 2013. Prevalence of foodborne pathogens and spoilage microorganisms and their drug resistant status in different street foods of Dhaka city. Agric. Food Anal.Bacteriol. J., 3: 281-292.

Tambekar, D. H., Jaiswal, V. J., Dhanorkar, D. V., Gulhane, P. B., Dudhane, M. N. 2009. Microbial quality and safety of street vended fruit juices: a case study of Amravati city. Internet J. Food Safety, 10: 72-76.

Tsang, D. 2002. Microbiological guidelines for ready to eat food. Road and Environmental Hygiene Department, Hongkong, 115-116.

Wimalasekara, Gunasena. 2016. Microbiological quality of ready-to-eat meat based food available in temporary food outlets in gall face green, Colombo, Srilanka. Int. J. Agric. Forest. Plant. 4: 38-44.

\section{How to cite this article:}

Abdullah Al Momen Sabuj, Zobayda Farzana Haque, Nanda Barua, Md. Alimul Islam and Sukumar Saha. 2018. Assessment of Bacteriological Quality of Street Vended Fast Foods and their Antimicrobial Resistance. Int.J.Curr.Microbiol.App.Sci. 7(11): 3049-3059.

doi: https://doi.org/10.20546/ijcmas.2018.711.350 